\title{
Pembangunan Ekonomi, Industrialisasi, dan Degradasi Lingkungan Hidup di Indonesia Tahun 1967-2013: Enviromental Kuznet Curve Model
}

\section{Andi Kurniawan}

\begin{abstract}
ABSTRAK
Penelitian ini bertujuan mengidentifikasi dampak pembangunan ekonomi dan proses industrialisasi terhadap Degradasi lingkungan di Indonesia baik dalam jangka panjang maupun jangka pendek. Untuk melihat pengaruh pembangunan ekonomi dan industrialisasi terhadap penurunan kualitas lingkungan di Indonesia, penelitian ini menggunakan model Enviromental Kuznet Curve (EKC) dan dengan model Error Correction Mechanism (ECM). Hasil penelitian menjelaskan bahwa dalam jangka panjang peningkatan pendapatan masyarakat dan industrilasasi berpengaruh positif secara linier terhadap peningkatan emisi $\mathrm{CO}_{2}$ dan pada tingkat pendapatan tertentu terjadi proses perbaikan lingkungan yang ditandai dengan penurunan emisi $\mathrm{CO}_{2}$. Namun dalam jangka pendek hanya industrialisasi yeng memberikan pengaruh pada peningkatan emisi $\mathrm{CO}_{2}$. Diharapkan adanya konsesus bersama antara pemerintah dan pelaku usaha (industri) dalam mengurangi dampak pencemaran serta adanya peningkatan kesadaran masyakat dalam membantu mengurangi kerusakan lingkungan hidup.
\end{abstract}

Kata kunci: pembangunan ekonomi, industrialisasi, degradasi, lingkungan hidup, Enviromnetal Kuznet Kurve, Error Correction Mechanism

\section{Economic Development, Industrialization, and Environmental Degradation in Indonesia 1967-2013: Enviromental Kuznet Curve Model}

\begin{abstract}
This study aims to identify the impact of economic development and industrialization to the environmental degradation in Indonesia, both in the long term and short term. To see the effect of economic development and industrialization to the environmental degradation in Indonesia, this research was used Environmental Kuznets Curve (EKC) model and the model of Error Correction Mechanism (ECM). The results of the study explain that in the long term, improvement of people's income and industrialization have positive effect linearly with the increase in $\mathrm{CO}_{2}$ emissions and at a certain income level there is a process improvement environment characterized by a decrease in $\mathrm{CO}_{2}$ emissions. But in the short term only industrialization which influence on the increase of $\mathrm{CO}_{2}$ emissions. Expected that the consensus between the government and businesses (industri) in reducing the impact of pollution and the increased awareness of society in helping to reduce environmental damage.
\end{abstract}

Keywords: economic development, industrialization, degradation, environmental, Enviromnetal Kuznets curve, Error Correction Mechanism

\section{PENDAHULUAN}

Menurut pengertian akademisi ilmu ekonomi, pembangunan (development) secara tradisional diartikan sebagai kapasitas dari sebuah perekonomian nasional-yang kondisi ekonomi awalnya kurang lebih bersifat statis dalam waktu yang cukup lama-untuk menciptakan dan mempertahankan kenaikan pendapatan nasional bruto atau GNI (Gross National Income). Indeks ekonomi lainnya yang juga sering digunakan untuk mengukur tingkat kemajuan pembangunan adalah tingkat pertumbuhan pendapatan per kapita (Income per Capita) atau GNI perkapita. (Todaro, 2006)

Pada masa lampau pembangunan ekonomi juga sering diukur berdasarkan tingkat kemajuan struktur produksi dan penyerapan tenaga kerja (employment) yang diupayakan secara terencana. Biasanya dalam proses tersebut peranan sektor pertanian menurun untuk memberi kesempatan bagi tampilnya sektor-sektor manufaktur dan jasajasa agar senantiasa berkembang. Oleh karena itu, 
Tabel 1. Jumlah Emisi Karbon Dioksida (Co2)

dan Emisi CO2 Perkapita Bebarapa Negara

\begin{tabular}{|c|l|r|r|r|}
\hline No. & Negara & $\begin{array}{c}\text { Emisi Co2 } \\
\text { perkapita } \\
\text { (Ton) }\end{array}$ & $\begin{array}{c}\text { Emisi Co2 } \\
\text { (Milyar } \\
\text { ton) }\end{array}$ & \multicolumn{1}{c|}{$\begin{array}{c}\text { Kontribusi } \\
\text { (\%) }\end{array}$} \\
\hline$(1)$ & \multicolumn{1}{|c|}{$(2)$} & \multicolumn{1}{c|}{$(3)$} & \multicolumn{1}{c|}{$(4)$} & \multicolumn{1}{c|}{$(5)$} \\
\hline 1 & China & 16.39 & 10.25 & 28.59 \\
\hline 2 & Amerika & 1.59 & 2.03 & 14.47 \\
\hline 3 & India & 12.47 & 1.79 & 4.68 \\
\hline 4 & Rusia & 9.76 & 1.24 & 3.47 \\
\hline 5 & Jepang & 9.22 & 0.76 & 2.11 \\
\hline 6 & Jerman & 8.00 & 0.62 & 1.72 \\
\hline 7 & Iran & 11.80 & 0.59 & 1.65 \\
\hline 8 & Korea Selatan & 17.93 & 0.54 & 1.51 \\
\hline 9 & Saudi Arabia & 2.47 & 0.50 & 1.41 \\
\hline 10 & Brazil & 3.95 & 0.49 & 1.36 \\
\hline 11 & Mexico & 1.91 & 0.48 & 1.34 \\
\hline 12 & Indonesia & 4.996 & 35.85 & 100.00 \\
\hline & Dunia & & & \\
\hline
\end{tabular}

Sumber : Bank Dunia

strategi biasanya berfokus pada upaya menciptakan industrialiasasi secara cepat sehingga kadangkala mengorbankan kepentingan pembangunan sektor pertanian dan daerah pada umumnya. (Todaro, 2006)

Dalam tahun-tahun terakhir ini, para ekonom semakin menyadari betapa pentingnya implikasi-implikasi yang ditimbulkan oleh persoalan lingkungan hidup terhadap upaya-upaya pembangunan ekonomi. Sekarang kita memahami bahwa interkasi antara kemiskinan dengan degradasi lingkungan dapat menjurus suatu proses perusakan tanpa henti. (Todaro, 2006)

Pembangunan ekonomi yang dilakukan oleh semua negara didunia ini termasuk Indonesia bertujuan untuk memberikan kemakmuran bagi masyakatnya, namun pembangunan ekonomi juga memberikan dampak negatif yang cukup serius yang dihadapi oleh setiap negara yaitu pencemaran lingkungan seperti; tercemarnya air, tanah dan udara serta rusaknya ekosistem dan lain sebagainya. Salah satu pencemaran lingkungan yang menjadi isu global adalah pemanasan global. Pemanasan global ini sebagai akibat naiknya konsentasi karbon dioksida $\left(\mathrm{CO}_{2}\right)$ serta jenis gas lainnya uang ada di atmosfir. Menurut data Bank dunia, emisi $\mathrm{CO}_{2}$ yang dihasilkan oleh negara-negara di dunia ini sebagai akibat aktifitas pembangunan yang dilakukan adalah sebanyak 35,85 milyar miliar ton emisi $\mathrm{CO}_{2}(\mathrm{MtCO} 2 \mathrm{e})$ per tahun. Dan Indonesia merupakan Negara yang memberikan konstribusi besar dalam menghasilkan emisi $\mathrm{C}_{2}$.

Tebel 1 diatas menggambarkan bahwa Indonesia merupakan salah satu negara yang memberikan sumbangan emisi $\mathrm{CO}_{2}$ yang cukup besar pada pencemaran dunia. Pada tahun 2013 sumbangan emisi $\mathrm{CO}_{2}$ Indonesia sebesar 0,48 Milyar Ton atau 1,34 persen menyumbang emisi $\mathrm{CO}_{2}$ dunia. Posisi Indonesia menduduki urutan ke-12 terbesar pemnyumbang emisi karbon dunia dengan emisi $\mathrm{CO}_{2}$ perkapita sebesar 1,91 ton perkapita per tahun.

Dalam dunia global, pembangunan yang memperhatikan faktor lingkungan juga menjadi pembahasan bersama. Pada 25 September 2015 di Markas Besar PBB, para pemimpin 193 negara anggota PBB mengadopsi Tujuan Pembangunan Berkelanjutan (SDGs) sebagai agenda pembangunan global yang baru untuk periode 2016-2030 yang merupakan kelanjutan dari Millennium Development Goals (MDGs). Terkait dengan peningkatan pendapatan masyakat, industrilasasi dan isu lingkungan secara lebih tegas diatur dalam beberapa point tujuan SDGs, diantaranya: (United Nation,2016)

- Mempromosikan pertumbuhan yang 
berkelanjutan, inklusif dan keberkelanjutan ekonomi, tenaga yang produktif dan pekerjaan yang layak bagi semua (tujuan ke-8 SDGs)

- Membangun infrastruktur tangguh, mempromosikan industrialisasi yang inklusif and berkelanjutan dan membantu pengembangan inovasi tujuan ke 8-SDGs)

- $\quad$ Tindakan mendesak untuk memerangi perubahan iklim dan dampaknya (tujuan ke-13 SDGs)

Pembangunan ekonomi berkelanjutan atau berkesinambungan dalam upaya memperjelas keseimbangan yang paling diinginkan antara pertumbuhan ekonomi disatu sisi dan pelestarian lingkungan hidup atau sumber daya alam disisi lainnya. (Todaro, 2006). Pembangunan ekonomi berkelanjutan merupakan upaya meningkatkan kesejateraan masyarakat dengan memperhatikan dampak lingkungan. Namun yang terjadi, peningkatan pendapatan masyarkat selalu diikuti oleh penurunan kualitas lingkungan seperti: deforestasi, tercemarnya sumber air, tercemarnya udara oleh berbagai jenis polutan. Salah satu indikator yang dapat dijadikan ukuran

\section{DATA DAN METODELOGI}

\section{Data dan Sumber Data}

Data yang digunakan dalam penelitian ini adalah data time series, tahun 1967-2013 yang bersumber dari Bank Dunia antara lain: jumlah emisi $\mathrm{CO}_{2}$, emisi $\mathrm{CO}_{2}$ perkapita, pendapatan perkapita atas dasar harga berlaku (nominal), PDB deflator, dan kontribusi nilai tambah sektor industri terhadap Produk Domestik Bruto (PDB).

Variabel dependen dalam penelitian ini adalah emisi $\mathrm{CO} 2$ perkapita sedangkan variabel independen antara lain: pendapatan perkapita riil, dan konstribusi nilai tambah sektor industri terhadap PDB. PDB perkapita riil diperoleh dengan cara membagi PDB perkapita nominal dengan PDB deflator.

\section{Metodelogi}

\section{a. Environmental Kuznets Curve}

Penelitian mengenai hubungan antara pertumbuhan ekonomi dan indikator kualitas lingkungan ini menggunakan konsep Environmental Kuznets Curve (EKC). EKC merupakan hipotesis hubungan antara berbagai macam indikator degradasi lingkungan dan pendapatan per kapita yang membentuk kurva $U$ terbalik. Pada awal pertumbuhan ekonomi terjadi peningkatan degradasi lingkungan, tetapi pada tingkat pendapatan per kapita tertentu terjadi perbaikan lingkungan (Stern, 1996). Panayotou (2003) membuat studi empiric mengenai EKC dengan persamaan umum sebagai berikut:

$\mathrm{CO}_{2 t}=\beta_{0}+\beta_{1} Y_{t}+\beta_{2} Y^{2}+\mathrm{b}_{3} Y^{3}{ }_{t} \varepsilon+\varepsilon_{t}$

Dimana $\mathrm{CO}_{2 \mathrm{t}}$ dan $\mathrm{y}_{\mathrm{t}}$ adalah emisi $\mathrm{CO}_{2}$ per kapita and PDB per capita dalam periode peneltian. Jika $\beta 1>0, \beta 2<0$ dan $\beta 3=0$ perekonomian mengikuti EKC.

Ang (2007) dan Iwata et al. (2010) dalam penelitian mengkaji model EKC dengan membentuk hubungan jangka panjang antara emisi $\mathrm{CO}_{2}$, pertumbuhan ekonomi, konsumsi energi dan perdagangan luar negeri dengan jiga berdasarkan konsep EKC mengunakan model logaritma. Penelitian ini juga mengunakan konsep EKC dengan membentuk hubungan jangka panjang antara antara emisi $\mathrm{CO}_{2}$, pertumbuhan ekonomi dan industrialisasi:

$\operatorname{Ln} E_{t}=\beta_{0}+\beta_{1} \operatorname{Ln} Y_{t}+\beta_{2} \operatorname{Ln}\left(Y_{t}\right)^{2}+\beta_{3}\left(Y_{t}\right)^{3}+\beta_{4}$ Ind $_{t}$

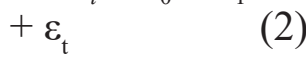

Dimana E adalah emisi $\mathrm{CO}_{2}$ per capita, $\mathrm{Y}$ merupakan PDB per capita real, dan Ind adalah share industri dalam perekonomian, dan et adalah Error term.

\section{b. Analisis Error Corection Mechanism}

Penelitian ini akan menggunakan analisis Error Correction Mechanism (ECM) model sebagai salah analisis data time series. ECM merupakan salah satu model dinamik yang diterapkan secara luas dalam analisis ekonomi. Model ECM pertama kali dipernalkan oleh Sargan dan dipopulerkan oleh Engle dan Granger, yaitu model yang digunakan untuk mengoreksi keseimbangan jangka pendek menuju keseimbangan jangka panjang (Nachrowi, 2006)

Hubungan jangka panjang antara emisi $\mathrm{CO}_{2}$, pertumbuhan ekonomi, dan industrialisasi atau terjadi kointegrasi antara varibel dependen $(\mathrm{Yt})$ dan variabel eksogen $(\mathrm{Xt})$. Gujarati menyatakan bahwa apabilai Yt dan Xt berkointegrasi, maka terdapat hubungan jangka panjang antara kedua variabel dan dalam jangka pendek akan terdapat ketidakseimbangan antara kedua variabel, sehingga Error term \&t dalam persamaan(2) dianggap sebagai equilibrium error. Error term menghubungkan perilaku jangka pendek menuju nilai jangka panjangnya. Berdasarkan teori yang disebut sebagai Granger Represetation Theorem,apabila 
Yt dan Xt berkointegrasi, sifat hubugan jangka pendek antara keduanya dapat dinyatakan dalam bentuk ECM Model (Gujarati,2003). Sehingga model ECM dalam penelitian ini sebagai berikut: $\Delta \operatorname{Ln} E_{t}=\beta_{0}+\beta_{1} \Delta \operatorname{Ln} Y_{t}+\beta_{2}\left(\Delta \operatorname{Ln} Y_{t}^{2}\right)+\beta_{3}\left(\Delta \operatorname{Ln} Y_{t}^{3}\right)$ $+\beta_{4} \Delta$ Ind $+\beta_{5} v_{t-1}+\varepsilon_{t}$

Dimana $\triangle \mathrm{E}$ adalah turunan pertama dari variabel emisi $\mathrm{CO}_{2}$ per capita, $\Delta Y$ merupakan turunan pertama dari variabel PDB per capita real, $\Delta$ Ind adalah turunan pertama dari variabel share industri dalam perekonomian, dan $\beta_{5}$ adalah speed of adjustment yang menunjukan seberapa cepat keseimbangan akan dikembalikan. Beberapa tahapan harus dilakukan dalam penggunaan analisis ECM yaitu: uji stasioneritas dan uji kointegrasi.

\section{Uji Stasioneritas}

Uji stasioner diperlukan karena permasalahan yang dimiliki oleh data time series adalah adanya otokorelasi. Otokorelasi menyebabkan data tidak stsioner, data yang tidak stasioner baik pada variabel dependen maupun variabel eksogen akan menghasilkan regresi palsu (spurius regression). Regresi palsu adalah situasi ketika hasil regresi akan terlihat baik dengan koefisien determinasi $\left(\mathrm{R}^{2}\right)$ yang tinggi dan uji hipotesis yag signifikan tetapi sebenarnya hubungan antar variabel di dalam model tidak memberi arti. (Nachrowi, 2006).

Pengujian stasioneritas dalam penelitian ini dilakukan dengan menggunakan Augmented Dicky-Fuller (ADF) Test. Pengujian ini merupakan penyesuaian dari Dicky-Fuller (ADF) Test. DF test mengasumsikan bahwa error independen atau tidak berkorelasi, sehingga $A D F$ test digunakan untuk mengatasi adanya korelasi pada error dengan menambahkan turunan lag dari variabel dependen. Penyederhanaan uji stasioneritas dimulai dari bentuk persamaan awal beriku: (Gujarati, 2003)

$$
\mathrm{Y}_{t}=\rho \mathrm{Y}_{t-1}+\mathrm{u}_{t}
$$

Dimana $\mathrm{Y}_{t}$ adalah variabel yang diamati pada periode $t, Y_{t-1}$ adalah variabel yang diamati pada periode $\mathrm{t}-1, \quad \rho$ merupakan koefisien autoregresi dan ut adalah white-noise Error term (residual bersifat random atau stokastik dengan rata-rata nol dan varians konstan serta tidak saling berhubungan). Apabila $\rho=1$, pada model (3) menjadi random walk tanpa trend yang memiliki unit root atau data tidak stasioner. Oleh karena itu, model (3) disederhanakan dengan cara mengurangkan $\mathrm{Y}_{t-1}$ pada kedua ruas, sehingga diperoleh: (Gujarati, 2003)

$$
\begin{aligned}
& \mathrm{Y}_{t}-\mathrm{Y}_{t-1}=\rho \mathrm{Y}_{t-1}+\mathrm{u}_{t}-\mathrm{Y}_{t-1} \\
& \Delta \mathrm{Y}_{t-1}=(\rho-1) \mathrm{Y}_{t-1}+\mathrm{u}_{t} \\
& \Delta \mathrm{Y}_{t-1}=\delta \mathrm{Y}_{t-1}+\mathrm{u}_{t}
\end{aligned}
$$

Dengan $\delta=\rho-1$ dan $\Delta \mathrm{Y}_{t-1}$ merupakan turunan pertama dari $\mathrm{Y}_{t}$. Model regresi yang digunakan dalam pengujian stasioner adalah sebagai berikut:

$$
\begin{aligned}
& \Delta \mathrm{Y}_{t-1}=\delta \mathrm{Y}_{t-1}+\mathrm{u}_{t} \\
& \Delta \mathrm{Y}_{t-1}=\beta_{0}+\delta \mathrm{Y}_{t-1}+\mathrm{u}_{t} \\
& \Delta \mathrm{Y}_{t-1}=\beta_{0}+\beta_{1} \mathrm{t}+\delta \mathrm{Y}_{t-1}+\mathrm{u}_{t}
\end{aligned}
$$

Asumsi yang digunakan pada persamaan (8) tanpa memperhitungkan trend dan konstanta, persamaan (9) memperhitungan konstanta dan persamaan (10) memperhitungkan trend dan kosntanta dalam pengujian akar unit. Pengujian stasioneritas melalui uji ADF dilakukan dengan cara menguji hipotesis dalam persamaan regresi berikut:

$$
\Delta Y_{t}=\delta Y_{t-1}+\sum_{i=1}^{m} a_{i} \Delta Y_{t-1}+\varepsilon_{t}
$$

\section{Uji Kointegrasi}

Uji kointegrasi dilakukan untuk melihat adanya kombinasi hubungan linier antar variabel. Menurut Nachrowi (2006), dua variabel dikatakan berkointegrasi saat kedua variabel tersebut masing-masing tidak stasioner tetapi kombinasi linier antara dua variabel tersebut stasioner. Menurut Rosadi (2012), masalah spurious regression akan hilang ketika terjadi kointegrasi dan dengan konsep kointegrasi dapat diamati hubungan equilibrium jangka panjang (long-run equilibrium) dari variabel-variabel yang tidak stasioner. Jika Error term atau vt pada model yang akan diteliti maka persamaan (1) disebut persamaan kointegrasi, sedangkan parameternya disebut sebagai parameter kointegrasi. Metode yang digunakan untuk pengujian ini adalah metode Engle-Granger atau Augmented Engle-Granger (AEG) Test dengan memanfaatkan uji DF dan ADF.(Gujarati, 2003).

Setelah uji stasioneritas dan uji kointegarasi, tahapan berikutnya adalah pengujian keberartian model dan pengujian asumsi klasik meliputi: Asumsi normalitas, asumsi homoskesdasitas, asumsi nonautokorelasi dan asumsi non multikolieritas.

\section{Uji Keberartian Model}

Uji keberartian model meliputi uji signifikansi simultan (F-Test), Uji signifikansi parameter individu (t-test) dan koefisien determinasi. Uji signifikansi simultan bertujuan untuk mengetahui apakah variabel independen 
secara bersama-sama mempunyai pengaruh yang signifikan terhadap variabel dependen. Berdasarkan persamaan (2) untuk model jangka panjang atau persamaan (3) untuk model ECM atau model jangka pendek, hipotesis yang diuji adalah sebagai berikut:

$\mathrm{H}_{0}: \beta_{1}=\beta_{2}=\ldots \mathrm{B}_{\mathrm{k}}$ (tidak ada variabel independen yang berpengaruh signifikan terhadap variabel dependen secara simultan

$\mathrm{H}_{1} \quad$ : minimal ada $\beta_{\mathrm{i}} \neq 0$, dengan $\mathrm{i}=1,2, . . \mathrm{k}$ (minimal terdapat satu variabel independen yang berpengaruh signifikan terhadap variabel dependen secara simultan

Satistik Uji: $F_{H i t}=\frac{S S R / k}{S S E /(n-k-1)}$

Dimana SSR adalah jumlah kuadrat regresi, SSE adalah jumlah kuadrat residual. Jika $\mathrm{F}_{\text {hit }}>\mathrm{F}_{\alpha ;(k, n-k-1)}$ atau $p$-value lebih kecil dari $\alpha$ maka keputusan yang diperoleh adalah tolak $\mathrm{H}_{0}$, artinya minimal ada satu variabel independen yang berpengaruh signifikan terhadap variabel dependen.

Uji signifikansi parameter individual ( $t$-test $)$ bertujuan untuk mengetajui apakah variabel independen secara parsial mempunyai pengaruh yang signifikan terhadap variabel dependen. Adapun hipitesis statistic yang diuji Berdasarkan persamaan (2) untuk model jangka panjang atau persamaan (3) untuk model ECM atau model jangka pendek, hipotesis yang diuji adalah sebagai berikut:

$\mathrm{H}_{0} \quad: \beta_{\mathrm{i}}=0$, dengan $\mathrm{i}=1,2, . . \mathrm{k}$ (tidak ada pengaruh dari variabel independen ke-i terhadap variabel dependen)

$\mathrm{H}_{1} \quad: \beta_{\mathrm{i}} \neq 0$, dengan $\mathrm{i}=1,2, .$. (ada pengaruh dari variabel independen ke-i terhadap variabel dependen)

Satistik Uii: $t_{H i t}=\frac{b_{i}}{s\left(b_{i}\right)}$

Dimana bi adalah nilai penduga parameter ke-I atau koefisien regresi ke-i, dan $\mathrm{s}\left(\mathrm{b}_{\mathrm{i}}\right)$ adalah standar error dari koefisien regresi ke-i. Jika $\left|\mathrm{t}_{\text {hit }}\right| \mathrm{t}_{\alpha / 2 ;(\mathrm{n}-\mathrm{k}-1)}$ atau $p$-value lebih kecil dari $\alpha$ maka keputusan yang diperoleh adalah tolak $\mathrm{H}_{0}$, artinya secara parsial variabel independen berpengaruh signifikan terhadap variabel dependen.

Koefisien determinasi $\left(\mathrm{R}^{2}\right)$ merupakan besaran yang digunakan untuk mengukur kebaikan dan kesesuaian (goodness of fit) suatu model regresi. Koefisien determinasi menunjukan persentase variasi total dalam variabel dependen yang mampu dijelaskan oleh variabel independen.
Koefisien determinasi dirimuskan sebagai berikut: $R^{2}=\frac{S S R}{S S T}$

Dimana SSR adalah jumlah kuadrat regresi, SSE adalah jumlah kuadrat residual dan SST adalah jumlah kuadrat total, SST $=\mathrm{SSR}+\mathrm{SSE}$.

\section{HASIL PEMBAHASAN \\ Gambaran Umum}

Keberhasilan pembangunan ekonomi di Indoenesia yang dilakukan sejak kemerdekaan sampai sekarang sangat terlihat, ditandai dengan meningkatnya ketersediaan fasilitiasfasilitas publik, dan terpenuhinya kebutuhan hidup masyarakat. Namun dampak lain dari pembangunan juga ada yaitu pencemaran lingkungan. Ukuran yang biasanya digunakan untuk melihat keberhasilan pembangunan adalah peningkatan pendapatan masyarakat, dan ukuran yang dijadikan indikator pencemaran lingkungan adalah emisi $\mathrm{CO}_{2}$. Gambar 2 menggambarkan indikator pembangunan ekonomi dan indikator pencemaran lingkungan (emisi $\mathrm{CO}_{2}$ ). Menurut gambar 2, terlihat bahwa selain PDB perkapita yang terus mengalami peningkatan, juga diikuti dampak negatif berupa peningkatan emisi $\mathrm{CO}_{2}$ yang menandakan terjadinya pencemaran lingkungan. Pada tahun 1967 ketika awal pembangunan orde baru pendapatan perkapita nominal sebesar US \$ 53,51 atau sebesar US \$ 0,32 dalam PDB perkapita riil dan emisi $\mathrm{CO}_{2}$ masih sangat rendah sebesar 0,23 ton perkapita. Dalam perkembangannya peningkatan pendapatan perkapita mencapai tingkat tertinggi pada tahun 2012 diikuti dengan peningkatan emisi $\mathrm{CO}_{2}$ perkapita dimana pendapatan perkapita nominal sebesar US \$ 3700,52 atau dalam PDB perkapita riil sebesar US \$ 985 sedangkan emisi $\mathrm{CO}_{2}$ mencapai 24,59 ton perkapita.

Gambar 1. Produk Domestik Bruto (PDB) Perkapita Nominal dan PDB Perkapita Rill dan Emisi Co2 Perkapita Tahun 1967-2013

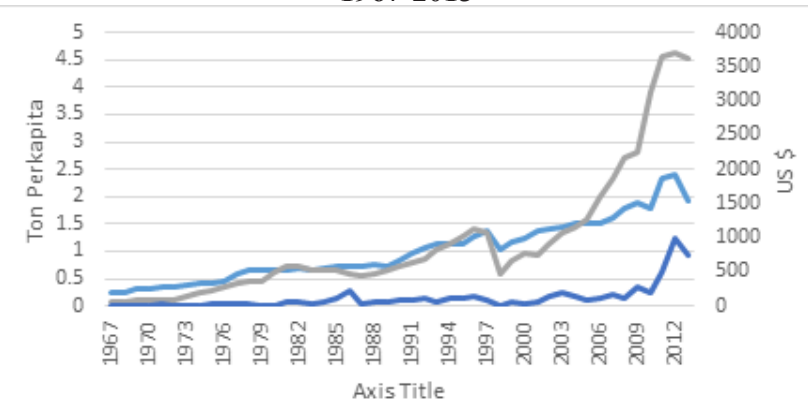

EmisicO2 PDB perkapita Nominal _ PDB perkapitariil

Sumber: Wordbank, data diolah 
Tabel 2. Hasil pengujian staioneritas variabel pada level

\begin{tabular}{|l|l|l|}
\hline \multicolumn{1}{|c|}{ Variabel } & Probabilitas & \multicolumn{1}{c|}{ Keputusan } \\
\hline \multicolumn{1}{|c|}{$(1)$} & $(2)$ & $(3)$ \\
\hline Ln $E_{t}$ & 0,3113 & Gagal Tolak Ho (Tidak Stasioner di level) \\
\hline Ln $\mathrm{Y}_{\mathrm{t}}$ & 0,0432 & Tolak Ho (Stasioner di level) \\
\hline${\text { Ln } \mathrm{Y}^{2}}_{\mathrm{t}}$ & 0,4944 & Gagal Tolak Ho (Tidak Stasioner di level) \\
\hline${\text { Ln } \mathrm{Y}^{3}}_{\mathrm{t}}$ & 0,7407 & Gagal Tolak Ho (Tidak Stasioner di level) \\
\hline Ind & 0,9988 & Gagal Tolak Ho (Tidak Stasioner di level) \\
\hline TR & 0,0671 & Tolak Ho (Stasioner di level) \\
\hline
\end{tabular}

Sumber : Hasil pengolahan (lampiran...)

Pembangunan ekonomi di Indonesia juga diikuti dengan pergeseran struktur ekonomi dari struktur ekonomi yang bertumpu pada sektor agraris menjadibertumpu disektor industri(industrialisasi). Lahan pertanian yang dulunya berisi tanaman dan pepohonan telah banyak berubah menjadi pabrikpabrik. Industrilasasi turut menjadi penyebab terjadi pencemaran lingkungan. Perubahan struktur ekonomi di Indonesia terlihat pada gambar diatas. Sejak tahun 1967 sektor pertanian menjadi sector yang memberikan kontribusi paling besar pada perekonomian Indonesia, 53, 94 persen perekonomian berasal dari sector pertanian dan hanya 7,31 persen kontribusi sector industri. Kemudian kontribusi sector pertanian dalam perkembangannya mengalami penurunan, hal terbalik terjadi pada sector industri yang kontribusinya semakin besar bagi perekonomian Indonesia. Sehingga pada tahun 1991, kontribusi sector industri lebih besar disbanding kontribusi sector pertanian. Tahun 2013 kontribusi sector industri sebesar 23,93 persen dan sector pertanian hanya sebesar 14,42 persen.

Gambar 2 Persentase Kontribusi Sektor pertanian dan Sektor Industri Terhadap PDB di Indonesia Tahun 1967 - 2013 (dalam Persen)

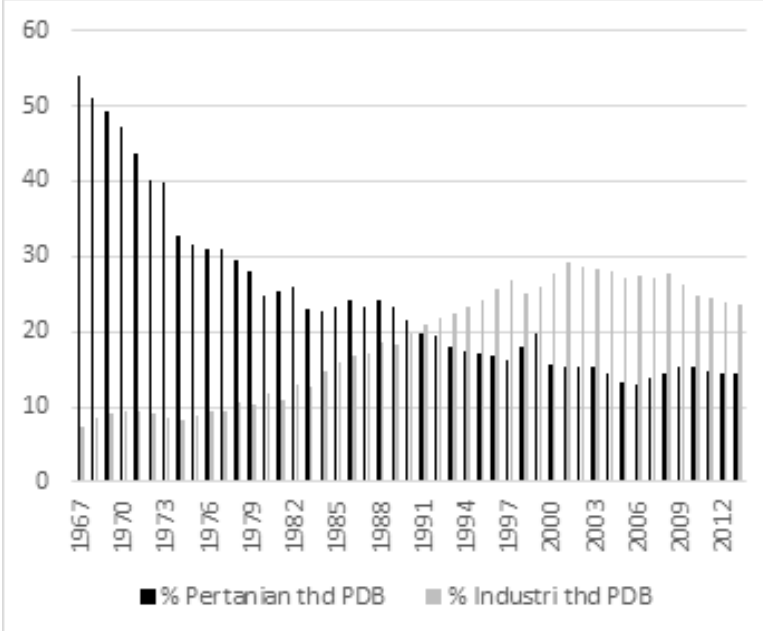

Sumber: Wordbank, data diolah

\section{Keseimbangan Jangka Panjang (Long-Run Equilibrium)}

Tehnik analisis ini digunakan untuk melihat hubungan jangka panjang dan jangka pendek antara Emisi $\mathrm{CO}_{2}$ dengan beberapa variabel independenseperti pendapatan perkapita riil, industrialisasi dan keterbukaan ekonomi adalah ECM. Salah satu syarat yang harus dipenuhi dalam ECM adalah stasioneritas data. Dalam penelitian ini, metode yang digunakan untuk melakukan pengujian stasioneritas data adalah uji akar unit Augmented Dickey-Fuller (ADF) yaitu melakukan pengujian pada persamaan regresi (11) dengan hipotesis nol yang digunakan adalah variabel yang diamati memiliki akar unit atau tidak stasioner.

Berdasarkan table 2, hasil pengujian stasioneritas memberikan kesimpulan beberapa variabel tidak stasioner di level yaitu variabel Ln Et, Ln Y2t, Ln Y3t dan Ind. Sedangkan variabel Ln Yt dan TR stasioner di level. Langkah selanjutnya adalah memeriksa stasioneritas pada difference pertama

Berdasarkan table 3, hasil pengujian stasioneritas memberikan keptusan Ho ditolak sehingga dapat disimpulkan bahwa dengan tingkat signifikansi 5 persen, seluruh variabel tidak memiliki akar unit atau dengan kata lain seluruh variabel Stasioner pada difference pertama.

Berdasarkan hasil pengujian stasioneritas beberapa variabel tidak stasioner pada level tetapi semu variabel stasioner pada difference pertama atau semua variabel terintegrasi. Estimasi persamaan jangka panjang adalah sebagai berikut: Ln Et $=-1.62+0.20$ Ln Y $_{t}^{*}-0.05 \operatorname{Ln~Y}_{t}^{2 *}+0.00$ $\mathrm{Ln} \mathrm{Y}_{t}^{3 *}+0.05$ IND $^{*}$

Kemudian kita lakukan pengujian kointegrasi pada persamaan jangka panjang dengan cara menguji stasioneritas residual. Berdasarkan hasil pengujian dengan menggunakan 
Tabel 3. Hasil pengujian staioneritas variabel pada difference pertama

\begin{tabular}{|l|l|c|}
\hline \multicolumn{1}{|c|}{ Variabel } & Probabilitas & \multicolumn{1}{c|}{ Keputusan } \\
\hline \multicolumn{1}{|c|}{$(1)$} & \multicolumn{1}{c|}{$(2)$} & $(3)$ \\
\hline Ln $\mathrm{E}_{\mathrm{t}}$ & 0,0000 & Tolak Ho (Stasioner di difference pertama) \\
\hline Ln $\mathrm{Y}_{\mathrm{t}}$ & 0,0000 & Tolak Ho (Stasioner di difference pertama) \\
\hline${\text { Ln } \mathrm{Y}^{2}}_{\mathrm{t}}$ & 0,0000 & Tolak Ho (Stasioner di difference pertama) \\
\hline Ln Y $^{3}$ & 0,0000 & Tolak Ho (Stasioner di difference pertama) \\
\hline Ind & 0,0000 & Tolak Ho (Stasioner di difference pertama) \\
\hline TR & 0,0000 & Tolak Ho (Stasioner di difference pertama) \\
\hline
\end{tabular}

Sumber : Hasil pengolahan (lampiran...)

Tabel 4. Hasil Estimasi Persamaan Jangka Panjang

\begin{tabular}{|l|r|r|r|}
\hline Variabel & \multicolumn{1}{|l|}{ Koefisien } & \multicolumn{1}{l|}{ t-statistik } & Prob. \\
\hline \multicolumn{1}{|r|}{$(1)$} & $(2)$ & $(3)$ & $(4)$ \\
\hline C & $-1,62$ & -21.26925 & 0.0000 \\
\hline Ln Y & 0,20 & 3.558124 & 0.0009 \\
\hline Ln Y & $-0,05$ & -1.879660 & 0.0671 \\
\hline Ln Y & 0,00 & 2.330385 & 0.0247 \\
\hline IND & 0,05 & 11.21776 & 0.0000 \\
\hline $\mathrm{R}^{2}$ & 0.937837 & F-statistic & 158.4120 \\
\hline $\mathrm{R}^{2}$ adj & 0.931917 & Prob(F-statistic) & 0.000000 \\
\hline
\end{tabular}

Sumber: Hasil pengolahan

Augmented Dickey-Fuller (lampiran 4) diperoleh keputusan tolak Ho dengan nilai nilai probabilitas 0,0040 yang lebih kecil dibandingkan alfa $(\alpha)$ sebesar 0,05 artinya dengan signifikansi 5 persen dapat disimpulkan bahwa residual tidak memiliki akar unit atau residual stasioner. Artinya terjadi kointegrasi pada persamaan jangka panjang.

Dengan memperhatikan persamaan jangka panjang dan kointegrasi dapat disimpulkan bahwa pertumbuhan pendapatan perkapita, dan industrialisasi signifikan memiliki hubungan yang postif dengan pertumbuhan emisi $\mathrm{CO}_{2}$. Penelitian ini membuktikan secara empiris bahwa dalam jangka panjang perekonomian yang dilihat dari peningkatan pendapatan perkapita dan industrialisiasi ternyata memberikan dampak terhadap peningkatan emisi $\mathrm{CO}_{2}$ (penurunan kualitas lingkungan).

Secara uji keseluruhan koefisien regresi (overall F-test), dari hasil penghitungan nilai Fhitung adalah sebesar 158,4120 dengan probabilita 0,0000 . Nilai probabilita $F$ lebih kecil dari alfa $(\alpha)$ sebesar 0,05 artinya dengan signifikansi 5 persen dapat disimpulkan bahwa minimal ada satu variabel independen yang berpengaruh signifikan secara statistik terhadap emisi $\mathrm{CO}_{2}$ dengan koefisien determinasi $\left(\mathrm{R}^{2}{ }_{\text {adj }}\right)$ sebesar 0,9319 artinya bahwa keragaman emisi $\mathrm{CO}_{2}$ dapat dijelaskan oleh variabel independennya (pendapatan perkapita riil dan industrialisasi). Sedangkan jika di uji secara parsial semua variabel independen secara parsial mempunyai pengaruh terhadap variabel dependen (table 4)

Adapun intepretasi persamaan jangka panjang adalah sebagai berikut:

- Pendapatan perkapita riil mempunyai pengaruh yang signifikan dengan tingkat signifikansi 10 persen baik secara linier, kuadratik, maupun kubik. Koefesien regresi secara linier sebesar 0,20 artinya peningkatan 1 persen pendapatan perkapita riil akan menyebabkan meningkatnya emisi $\mathrm{CO}_{2}$ sebesar 0,2 persen. Sedangkan koefisien regresi secara kuadratik yang bertanda negatif $(-0,05)$ bermakna pada pendapatan perkapita riil tertentu akan terjadi penurunan emisi $\mathrm{CO}_{2}$ (perbaikan lingkungan) dan nilai koefisien regresi kubik sebesar 0,00. Dalam persamaan jangka panjang terlihat $\beta_{1}>0, \beta_{2}<0$ dan $\beta_{3}=0$ perekonomian di Indonesia pada periode 1967-2013 mengikuti EKC seperti penelitian yang dilakukan oleh Panatayotou (2003). 
Tabel 5. Hasil Estimasi Persamaan Jangka Pendek

\begin{tabular}{|c|c|c|c|}
\hline Variabel & Koefisien & t-statistik & Prob. \\
\hline$(1)$ & $(2)$ & (3) & (4) \\
\hline $\mathrm{C}$ & 0,02 & 1.764072 & 0.0854 \\
\hline $\operatorname{Ln} Y$ & 0,07 & 1.574015 & 0.1234 \\
\hline $\operatorname{Ln} Y^{2}$ & $-0,02$ & -1.538646 & 0.1318 \\
\hline $\operatorname{Ln} Y^{3}$ & 0,00 & 2.007937 & 0.0514 \\
\hline IND & 0,03 & 2.353424 & 0.0236 \\
\hline $\mathrm{U}(-1)$ & $-0,16$ & -1.971652 & 0.0556 \\
\hline $\mathrm{R}^{2}$ & 0.937837 & F-statistic & 158.4120 \\
\hline $\mathrm{R}^{2} \mathrm{adj}$ & 0.931917 & Prob(F-statistic) & 0.000000 \\
\hline
\end{tabular}

- Industrialisasi memunyai pengaruh yang signifikan dengan tingkat signifikansi 10 persen. Koefisien regresi sebesar 0,05 artinya peningkatan struktur industri dalam perekonomian sebesar 1 persen akan meyebabkan meningkatnya emisi $\mathrm{CO} 2$ sebesar 0,05 persen

\section{Keseimbangan Jangka Pendek (Short-Run Equilibrium)}

Kemudian perlu kita melihat bagaimana hubungan jangka pendek, persamaan ECM akan melihat bagaimana pola ketidakeseimbangan jangka pendek mencapai keseimbangan jangka panjang. Persamaan ECM diestimasi dengan memasukan lag pertama variabel error term yang terdapat dalam persamaan jangka panjang dan dinotasikan dengan $\mathrm{u}_{\mathrm{t}}$ - . Hasil estimasi dari persamaan tersebut adalah sebagai berikut:

$\mathrm{LnEt}=0,02+0,07 \mathrm{Ln} \mathrm{Y}_{t}^{*}-0.02 \mathrm{Ln} \mathrm{Y}_{t}{ }^{*}+0.00 \mathrm{Ln}$ $\mathrm{Y}_{t}^{3 *}+0.03 \mathrm{IND}^{*}-0,16 \mathrm{U}_{t-1}$

Untuk melihat hubungan jangka pendek, selanjutnya dilakukan uji baik secara keseluruhan maupun secara parsial. Secara uji keseluruhan koefisien regresi (overall F-test), dari hasi penghitungan nilai Fhitung adalah sebesar 4,656 dengan probabilita 0,0019 . Nilai probabilita F lebih kecil dari alfa $(\alpha)$ sebesar 0,05 artinya dengan signifikansi 5 persen dapat disimpulkan bahwa minimal ada satu variabel independen yang berpengaruh signifikan secara statistik terhadap emisi $\mathrm{CO}_{2}$. Sedangkan jika di uji secara parsial variable, pendapatan perkapita secara kubik, struktur industri dan speed of adjustment yang mempunyai pengaruh signifikan terhadap variabel dependen. Koefisien ut-1 yang terdapat dalam persamaan jangka pendek menunjukan nilai negatif dan signifikan sebersar $-0,16$ persen menunjukan bahwa ketidakseimbangan tahun sebelumnya akan terkoreksi pada tahun sekarang sebesar 16 persen. (table 5)

Adapun intepretasi dari persamaan jangka pendek adalah sebagai berikut:

- Koefesien regresi secara linier sebesar 0,20; koefisien regresi secara kuadratik bertanda negatif $(-0,02)$ dan koefisien regresi kubik sebesar 0,00 . Dalam persamaan jangka pendek ini terlihat $\beta_{1}>0$ ,$\beta_{2}<0$ dan $\beta_{3}=0$ mengikuti EKC namun hanya koefisien kubik ( $\beta 3$ ) yang berpengaruh signifikan. Artinya dalam jangka pendek pendapatan perkapita tidak memberikan pengaruh yang signifiknan terhadap peningkatan emisi $\mathrm{CO}_{2}$.

- Industrialisasi dalam jangka pendek ternyata mempunyai pengaruh yang signifikan dengan tingkat signifikansi 5 persen. Koefisien regresi sebesar 0,03 artinya peningkatan struktur industri (industrialisasi) dalam perekonomian sebesar 1 persen akan meyebabkan meningkatnya emisi $\mathrm{CO}_{2}$ sebesar 0,03 persen.

\section{SIMPULAN \\ DAN \\ REKOMENDASI KEBIJAKAN \\ Simpulan}

Pembangunan ekonomi di Indonesia berhasil meningkatkan pendapatan masyarakat menjadi lebih baik. Pembangunan ekonomi juga menyebabkan perubahan struktur ekonomi dari perekonomian agraris ke Industri. Penelitian ini menunjukan bahwa peningkatan pendapatan masyarakat ternyata diikuti dengan masalah yang cukup serius yaitu penurunan kualitas lingkungan, terlihat dengan meningkatnya emisi $\mathrm{CO}_{2}$. Proses industrialisasi ternyata juga mempunyai pengaruh yang signifikan terhadap peningkatan emisi $\mathrm{CO}_{2}$. 
Selain itu penelitian ini juga menyimpulkan bahwa pada suatu tingkat pendapatan tertentu terjadi proses perbaikan lingkungan yang ditandai dengan penurunan emisi $\mathrm{CO}_{2}$.

\section{Rekomendasi Kebijakan}

Peran sektor industri yang semakin menguat harus disertai dengan berbagai kebijakan pembangunan yang berorientasi pembangunan lingkungan antara lain adanya konsesus bersama antara pemerintah dan pelaku usaha (industri) dalam mengurangi dampak pencemaran seperti mengganti energi fosil dengan sumber energi bersih dan terbarukan, adanya pengaturan oleh pemerintah mengenai Corporate Social Responsibility oleh perusahaan dalam wujud perbaikan lingkungan, adanya pengaturan mengenai alih guna lahan pertanian sehingga alih guna lahan tidak merusak lingkungan. Selain pelaku usaha, hendaknya ada himbuan dari pemerintah kepada masyarakat dalam membantu mengurangi kerusakan lingkungan hidup seperti perilaku hemat energi dan konsumsi energi yang lebih ramah lingkungan, penanaman pohon di sekitar rumah.

\section{REFERENSI}

Ang, J. (2007). CO2 emissions, energy consumption, and output in France. Energy Policy, 35 (10), 4772-4778. http:// dx.doi.org/10.1016/j.enpol.2007.03.032

Gujarati, D. (2003). Basic Econometrics, Fourth Edition. New York: MCGraw-Hill.

Iwata, H., Okada, K., \& Samreth, S. (2010). Empirical study on environmental Kuznets curve for $\mathrm{CO} 2$ in France: the role of nuclear energy. Energy Policy, 38, 4057-4063. http://dx.doi.org/10.1016/ j.enpol.2010.03.031

Mota, R. (2006) Determinants of CO2 emissions in open economies: testing the Environmental Kuznets Curve hypothesis (1970-2000). $10 \quad$ Maret 2017. https://mpra.ub.uni-muenchen.de/ 13342/

Nachrowi. (2006). Pendekatan Populer dan Praktis EKONOMTERIKA untuk analisis Ekonomi dan Keuangan. Jakarta: Lembaga Penerbit Fakultas Ekonomi
Rosadi, D (2012). Ekonometrika dan Analisis Runtun waktu Terapan dengan Eviews.

Stern, D., 2004. The rise and fall of the Environmental Kuznets Curve. World Development. $10 \quad$ Maret 2016. www.steadystate.org/wp-content/.../Stern_ KuznetsCurve.pdf

Todaro, M.(2006). Pembangunan Ekonomi, Edisi Kesembilan. Jakarta: Airlangga.

UnitedNation.(2016). TheSustainableDevelopment Goals Report 2016. 7 maret 2017 https://sustainabledevelopment.un.org/

Wordbank. (2017). Data woldrbank. 7 Maret 2017 ht tps://data.worldbank.org/ 


\section{LAMPIRAN}

Lampiran 1. Pengujian Stasioneritas

Variabel Emisi CO2

Data Level

Null Hypothesis: LE has a unit root

Exogenous: Constant

Lag Length: 0 (Automatic - based on SIC, maxlag=9)

\begin{tabular}{lccc}
\hline \hline & t-Statistic & Prob. $^{*}$ \\
\hline \hline Augmented Dickey-Fuller test statistic & -1.940782 & 0.3113 \\
\hline Test critical values: & 1\% level & -3.581152 & \\
& $5 \%$ level & -2.926622 & \\
& $10 \%$ level & -2.601424 & \\
\hline \hline
\end{tabular}

*MacKinnon (1996) one-sided p-values.

Data Difference pertama

Null Hypothesis: $\mathrm{D}(\mathrm{LE})$ has a unit root

Exogenous: Constant

Lag Length: 1 (Automatic - based on SIC, maxlag=9)

\begin{tabular}{lccc}
\hline \hline & t-Statistic & Prob. $^{*}$ \\
\hline \hline Augmented Dickey-Fuller test statistic & -5.986569 & 0.0000 \\
\hline Test critical values: & $1 \%$ level & -3.588509 & \\
& $5 \%$ level & -2.929734 & \\
& $10 \%$ level & -2.603064 & \\
\hline \hline
\end{tabular}

*MacKinnon (1996) one-sided p-values.

Variabel Pendapatan Perkapita Riil

Data Level

Null Hypothesis: LY has a unit root

Exogenous: Constant

Lag Length: 0 (Automatic - based on SIC, maxlag=9)

\begin{tabular}{lrcc}
\hline \hline & t-Statistic & Prob. $^{*}$ \\
\hline \hline Augmented Dickey-Fuller test statistic & -2.990563 & 0.0432 \\
\hline Test critical values: & 1\% level & -3.581152 & \\
& $5 \%$ level & -2.926622 & \\
& $10 \%$ level & -2.601424 & \\
\hline \hline
\end{tabular}

*MacKinnon (1996) one-sided p-values. 
Null Hypothesis: LY2 has a unit root Exogenous: Constant Lag Length: 0 (Automatic - based on SIC, maxlag=9)

\begin{tabular}{|c|c|c|c|}
\hline & & t-Statistic & Prob.* \\
\hline \multicolumn{2}{|c|}{ Augmented Dickey-Fuller test statistic } & -1.560352 & 0.4944 \\
\hline Test critical values: & $\begin{array}{c}1 \% \text { level } \\
5 \% \text { level } \\
10 \% \text { level }\end{array}$ & $\begin{array}{l}-3.581152 \\
-2.926622 \\
-2.601424\end{array}$ & \\
\hline
\end{tabular}

${ }^{\star}$ MacKinnon (1996) one-sided p-values.

Null Hypothesis: LY3 has a unit root Exogenous: Constant Lag Length: 0 (Automatic - based on SIC, maxlag=9)

\begin{tabular}{|c|c|c|c|}
\hline & & t-Statistic & Prob. * \\
\hline \multicolumn{2}{|c|}{ Augmented Dickey-Fuller test statistic } & -1.013710 & 0.7407 \\
\hline Test critical values: & $\begin{array}{c}1 \% \text { level } \\
5 \% \text { level } \\
10 \% \text { level }\end{array}$ & $\begin{array}{l}-3.581152 \\
-2.926622 \\
-2.601424\end{array}$ & \\
\hline
\end{tabular}

${ }^{*}$ MacKinnon (1996) one-sided p-values.

Data Difference pertama

Null Hypothesis: D(LY2) has a unit root

Exogenous: Constant

Lag Length: 0 (Automatic - based on SIC, maxlag=9)

\begin{tabular}{lrrr}
\hline \hline & t-Statistic & Prob. $^{*}$ \\
\hline \hline Augmented Dickey-Fuller test statistic & -8.905027 & 0.0000 \\
\hline Test critical values: & $1 \%$ level & -3.584743 & \\
& $5 \%$ level & -2.928142 & \\
& $10 \%$ level & -2.602225 & \\
\hline \hline
\end{tabular}

${ }^{\star}$ MacKinnon (1996) one-sided p-values.

Null Hypothesis: D(LY3) has a unit root

Exogenous: Constant

Lag Length: 0 (Automatic - based on SIC, maxlag=9)

\begin{tabular}{lccc}
\hline \hline & t-Statistic & Prob. $^{*}$ \\
\hline \hline Augmented Dickey-Fuller test statistic & -8.416444 & 0.0000 \\
\hline Test critical values: & $1 \%$ level & -3.584743 & \\
& $5 \%$ level & -2.928142 & \\
& $10 \%$ level & -2.602225 & \\
\hline \hline
\end{tabular}

*MacKinnon (1996) one-sided p-values. 
Variabel Pendapatan Perkapita Riil

Data Level

Null Hypothesis: IND has a unit root

Exogenous: Constant, Linear Trend

Lag Length: 0 (Automatic - based on SIC, maxlag=9)

\begin{tabular}{lrrr}
\hline \hline & t-Statistic & Prob. $^{*}$ \\
\hline \hline Augmented Dickey-Fuller test statistic & 0.446923 & 0.9988 \\
\hline Test critical values: & $1 \%$ level & -4.170583 & \\
& $5 \%$ level & -3.510740 & \\
& $10 \%$ level & -3.185512 & \\
\hline \hline
\end{tabular}

${ }^{\star}$ MacKinnon (1996) one-sided p-values.

Data Diference Pertama

Null Hypothesis: D(IND) has a unit root

Exogenous: Constant, Linear Trend

Lag Length: 0 (Automatic - based on SIC, maxlag=9)

\begin{tabular}{|c|c|c|}
\hline & t-Statistic & Prob.* \\
\hline Augmented Dickey-Fuller test statistic & -6.320179 & 0.0000 \\
\hline $\begin{array}{cc}\text { Test critical values: } & 1 \% \text { level } \\
& 5 \% \text { level } \\
10 \% \text { level }\end{array}$ & $\begin{array}{l}-4.175640 \\
-3.513075 \\
-3.186854\end{array}$ & \\
\hline
\end{tabular}

*MacKinnon (1996) one-sided p-values.

Lampiran 2. Persamaan jangka panjang

Dependent Yariabel: LE

Method: Least Squares

Date: 03/13/17 Time: 11:35

Sample: 19672013

Included observations: 47

\begin{tabular}{crlrr}
\hline \hline \multicolumn{1}{c}{ Variabel } & Coefficient & Std. Error & t-Statistic & Prob. \\
\hline \hline C & -1.621592 & 0.076241 & -21.26925 & 0.0000 \\
LY & 0.205400 & 0.057727 & 3.558124 & 0.0009 \\
LY2 & -0.045579 & 0.024249 & -1.879660 & 0.0671 \\
\multicolumn{1}{c}{ IND } & 0.006086 & 0.002612 & 2.330385 & 0.0247 \\
\hline \hline R-squared & 0.051505 & 0.004591 & 11.21776 & 0.0000 \\
Adjusted R-squared & 0.937837 & Mean dependent var & -0.162457 \\
S.E. of regression & 0.931917 & S.D. dependent var & 0.611895 \\
Sum squared resid & 0.159660 & Akaike info criterion & -0.731254 \\
Log likelihood & 1.070634 & Schwarz criterion & -0.534430 \\
F-statistic & 22.18446 & Hannan-Quinn criter & -0.657187 \\
Prob(F-statistic) & 158.4120 & Durbin-Watson stat & 0.681877 \\
Prod & 0.000000 & &
\end{tabular}


Lampiran 3: Persamaan Jangka Pendek

Dependent Yariabel: D(LE)

Method: Least Squares

Date: 03/13/17 Time: 11:48

Sample (adjusted): 19682013

Included observations: 46 after adjustments

\begin{tabular}{crrrr}
\hline \hline \multicolumn{1}{c}{ Variabel } & Coefficient & Std. Error & t-Statistic & Prob. \\
\hline \hline C & 0.023228 & 0.013167 & 1.764072 & 0.0854 \\
D(LY) & 0.070376 & 0.044711 & 1.574015 & 0.1234 \\
D(LY2) & -0.022334 & 0.014516 & -1.538646 & 0.1318 \\
D(LY3) & 0.003228 & 0.001607 & 2.007937 & 0.0514 \\
D(IND) & 0.031725 & 0.013481 & 2.353424 & 0.0236 \\
U(-1) & -0.167587 & 0.084998 & -1.971652 & 0.0556 \\
\hline \hline & 0.367880 & Mean dependent yar & 0.045811 \\
R-squared & 0.288865 & S.D. dependent var & 0.095893 \\
Adjusted R-squared & 0.080865 & Akaike info criterion & -2.070953 \\
S.E. of regression & 0.261569 & Schwarz criterion & -1.832435 \\
Sum squared resid & 53.63193 & Hannan-Quinn criter & -1.981603 \\
Log likelihood & 4.655820 & Durbin-Watson stat & 1.632435 \\
F-statistic & 0.001923 & & & \\
Prob(F-statistic) & & & & \\
\hline \hline
\end{tabular}

Lampiran 4: Uji kointegrasi

Null Hypothesis: U has a unit root

Exogenous: Constant

Lag Length: 0 (Automatic - based on SIC, maxlag=9)

\begin{tabular}{lrrr}
\hline \hline & t-Statistic & Prob. \\
\hline \hline \multicolumn{2}{l}{ Augmented Dickey-Fuller test statistic } & -3.915002 & 0.0040 \\
\hline Test critical values: & $1 \%$ level & -3.581152 & \\
& $5 \%$ level & -2.926622 & \\
& $10 \%$ level & -2.601424 & \\
\hline \hline
\end{tabular}

${ }^{\star}$ MacKinnon (1996) one-sided p-values. 